\title{
EFFECT OF SOWING TIME ON GROWTH, PRODUCTIVITY AND NET RETURNS OF ADVANCED COTTON (GOSSYPIUM HIRSUTUM L.) CULTIVARS UNDER THE AGROCLIMATIC CONDITIONS OF SOUTHERN PUNJAB, PAKISTAN
}

\author{
Hussain, S. - Ali, H. - Hussain, G. S. \\ Department of Agronomy, Faculty of Agricultural Sciences and Technology, Bahauddin \\ Zakariya University, Multan 66000, Pakistan \\ *Corresponding author \\ e-mail: hha94@bzu.edu.pk \\ (Received 12 $2^{\text {th }}$ Mar 2020; accepted $11^{\text {th }}$ Aug 2020)
}

\begin{abstract}
Cotton (Gossypium hirsutum L.) as an important fiber crop is considered the back bone of Pakistan's economy. Climatic variations causing shift in cropping systems in Pakistan and worldwide. So, it is high time to readjust sowing times. Nutrient deficiency in cotton crops along with delayed sowing has made this situation worse. For this purpose, a two-year field study was carried out at the Central Cotton Research Institute (CCRI) Multan, Punjab, Pakistan during 2016 and 2017. The experiment was laid out in Randomized Complete Block Design (RCBD) with split plot arrangements with three replications. Experimental treatments comprised of five sowing dates viz. $S_{1}=15^{\text {th }}$ April, $S_{2}=01^{\text {st }}$ May, $\mathrm{S}_{3}=15^{\text {th }}$ May, $\mathrm{S}_{4}=01^{\text {st }}$ June and $\mathrm{S}_{5}=15^{\text {th }}$ June and three cultivars viz. $\mathrm{G}_{1}=\mathrm{CIM}-620, \mathrm{G}_{2}=$ Cyto- 120 and $\mathrm{G}_{3}=\mathrm{CIM}-608$. Sowing time significantly influenced the performance of different cotton cultivars. Each delay in sowing dates significantly reduced the seed cotton yield as the lowest yield $\left(1387 \mathrm{~kg} \mathrm{ha}^{-1}\right)$ and $\left(1264 \mathrm{~kg} \mathrm{ha}^{-1}\right)$ was produced with late sown cotton (June $15^{\text {th }}$ ) while the highest seed cotton yield (2759 $\mathrm{kg} \mathrm{ha}^{-1}$ and $2569 \mathrm{~kg} \mathrm{ha}^{-1}$ ) was produced when crop was sown early on $15^{\text {th }}$ April during both study years 2016 and 2017, respectively. Moreover, cultivars also significantly differ under different sowing dates. Cultivar (CIM-620) produced significantly more seed cotton yield $\left(2456 \mathrm{~kg} \mathrm{ha}^{-1}\right.$ and $\left.2257 \mathrm{~kg} \mathrm{ha}^{-1}\right)$ than (CIM-608) that produced $1971 \mathrm{~kg} \mathrm{ha}^{-1}$ and $1773 \mathrm{~kg} \mathrm{ha}^{-1}$ of seed cotton yield during 2016 and 2017 respectively. In conclusion; the cultivar (CIM-620) results in increased seed cotton yield (24.61 and $27.30 \%$ ) and lint percentage with more fiber brightness. Similarly, the performance of crop sown earlier on $15^{\text {th }}$ May produced higher number of fruiting points, more intact fruits and higher number of bolls. It is directed to the cotton growers not to adopt late sowing with any cultivar particularly CIM-620 for which $15^{\text {th }}$ May is a fairly good suggestion to improve its seed yield with optimum net returns.
\end{abstract}

Keywords: climate, cropping patterns, seed cotton yield

\section{Introduction}

Cotton crop plays a major role in the economy of Pakistan and serves as a white gold. It occupies a prominent position in our textile as well as edible oil industry (Government of Pakistan, 2017-18;). Cotton represents the source of basic inputs for the textile industry (Killi et al., 2005), oil expelling and spindle units around the world (Ahmed et al., 2009; Ali and Hameed, 2011). Pakistan is facing continuously lower yield of cotton as compared to other countries. Poor management of soil fertility like improper and unbalanced use of fertilizers is a major reason of low cotton yield in Pakistan (Ali et al., 2009).

Ideal sowing time for a cultivar is thought to be the most vital factor in cotton (Bachubhai et al., 2018; Bozbek et al., 2006). Early sowing seems to cause higher yield potential and a few reports have demonstrated that early sowing of cotton results in extensive tallness of plants with higher number of branches, bolls and seed cotton yield 
(Ali et al., 2009; and Farid et al., 2017). Early sowing produces 10\% more blooms, 23\% more open bolls and $18 \%$ more seed cotton yield than late sowing. Late planting of cotton indicates vegetative development and hard to oversee bringing about lower seed cotton yield (Farid et al., 2017). Impact of sowing dates and capability of nitrogen fertilizer are necessary factors to check the response of cotton cultivar for its growth and performance under semi-arid conditions (Liu et al., 2015). Cotton fiber quality is for the most part impacted by cultivars yet agronomic practices and ecological conditions are the secondary elements affecting fiber quality (Subhan et al., 2001). Earlier planting of cotton produced more yield and yield components like sympodial branches, average boll weight and ginning out turn than late planting (Arshad et al., 2007; and Farid et al., 2017).

Cultivars vary in their genetic makeup and respond different to various biotic as well as abiotic stresses and climatic conditions. So, cultivar selection and proper sowing time are keys to enhance seed cotton yield under different agro-ecological zones (Bange and Milroy, 2004; Farid et al., 2017). Different cultivars have their own genetic makeup to develop canopy, those having slow growth rate have less leaf area index resulting reduced efficiency of converting radiant light to photosynthates (Iqbal et al., 2012).

Keeping in view the importance of cotton crop and climatic variations of this region, this comprehensive study was planned to assess the reaction of various cotton cultivars under different sowing time, to characterize the ideal sowing time and its impact on yield contributing characteristics and to evaluate the response of various cultivars under agro-environmental conditions of Multan, Pakistan.

\section{Materials and methods}

\section{Experimental site and design}

The experiment was carried out at Central Cotton Research Institute Multan, Pakistan in 2016 and 2017. The climate of this section is subtropical and semi-arid with very hot summers and cold winters. The temperature varies from summer to winter as the area is situated in subtropical region. The latitude and longitude of Multan is $30.26^{\circ} \mathrm{N}$ and $71.51^{\circ} \mathrm{E}$, respectively. The experiment was planned under (RCBD) split plot arrangements with a net plot size of $7.5 \mathrm{~m} \times 9 \mathrm{~m}$.

\section{Soil sampling and analytical methods}

Soil samples were taken up to the depth of $30 \mathrm{~cm}$ with a sequence of $0-15 \mathrm{~cm}$ and $15-30 \mathrm{~cm}$ was taken from the experimental area. Three cores were taken from each depth, air dried, and ground, finally passed through a sieve $2 \mathrm{~mm}$ in diameter and all the samples were then mixed to get a composite sample and analyzed chemically. Physical and chemical characteristics of the soil were determined by using standard procedures. Soil sampling and chemical analysis of soil were repeated after harvest of each crop.

\section{Crop husbandry}

For seed bed preparation, initial irrigation with $4 \mathrm{~cm}$ depth was applied to make the soil in appropriate wattar condition which was followed by three cultivations and planking for sowing of cotton crop. Each experimental unit was sown on ridges with a tractor mounted ridger. The sowing was done by using single row hand drill at $2 \mathrm{~cm}$ depth vertically with $\mathrm{R} \times \mathrm{R}$ distance of $20 \mathrm{~cm}$. Thinning was done to maintain the required plant population 20-25 days after sowing. Recommended doses of phosphorus 
and potassium fertilizers i.e. $60 \mathrm{~kg} \mathrm{ha}^{-1}$ and $60 \mathrm{~kg} \mathrm{ha}^{-1}$ were used as per standard practices respectively.

Weeding and recommended plant protection measures were used for the control of insect and pests. Amidachloprid (Sun Crop Pesticide Ltd.) was used to control the attack of sucking insects and to protect the plant at vegetative stage, after that biphenthrin (KanzoAgri-group) was applied when chewing insects were observed at the flowering stage of crop plants. Chloroperephos (Four brothers Ltd.) was used to lessen the intensity of termites that was further helpful to reduce the crop yield. The picking of the cotton crop was done during the $2^{\text {nd }}$ week of November of both the study years.

\section{Observations recorded}

For measuring the plant height, number of nodes plant $^{-1}$ and internodal distance, ten random plants were initially selected and properly tagged for measuring the crop data. After that their average was taken and then statistically analyzed.

Leaf area index of the crop was measured with the ratio between leaf area and ground area of the cotton crop as the formula given by Watson et al. (1952). The crop growth rate of the plants was calculated during the whole crop growth season by using the formula as suggested by Hunt et al. (1978):

$$
\operatorname{CGR}\left(\mathrm{g} \mathrm{m}^{-2} \text { day }^{-1}\right)=\left(\mathrm{W}_{2}-\mathrm{W}_{1}\right) /\left(\mathrm{T}_{2}-\mathrm{T}_{1}\right)
$$

Ten different plants of cotton from each experimental unit were selected to find out the total fruiting points and Number of bolls plant ${ }^{-1}$. The total number of bolls plant ${ }^{-1}$ were calculated in each experimental unit on per meter square basis and their average was calculated. The average was taken after calculating the total number of plants and their weight in grams were taken by using weighing balance. Before final harvest, picking of the bolls was done to calculate the seed cotton yield for each experimental unit. After picking, their staple length in mm was measured by adopting standard method. The strength of the fiber was measured in grams per tax.

\section{Net income}

Net income was calculated by using the following formula, as given:

$$
\text { Net Income }=\text { Gross income }- \text { Total cost }
$$

\section{Benefit cost ratio}

Benefit cost ratio was calculated by using the formula:

$$
\mathrm{BCR}=\frac{\text { Gross income }\left(\text { Rs.ha }{ }^{-1}\right)}{\text { Total cost }\left(\text { Rs.ha }{ }^{-1}\right)}
$$

\section{Statistical analysis}

For the evaluation of every experiments in statistical manner, specific statistical design was used. to assess the effect of different dependent and independent variables Fisher's analysis of variance technique was applied and differences among treatment 
means was statistically calculated and compared through least significant difference test (LSD) at $0.05 \%$ probability level.

\section{Results}

Results showed that there were significant differences among different treatments i.e. sowing dates and cultivars (Table 1). Crop which was sown early on the $15^{\text {th }}$ April, gave the tallest plants $(129 \mathrm{~cm})$ and the crop sown late on the $15^{\text {th }}$ June produced significantly the shortest plants $(74.7 \mathrm{~cm})$. However, crop sown on the $1^{\text {st }}$ June tended to produce shorter plants $(108$ and $104 \mathrm{~cm})$ than treatments $(75$ and $75 \mathrm{~cm})$ on the $15^{\text {th }}$ May and statistically significant differences were observed among these treatments during both years of experiment. Among different cultivars, CIM-620 produced significantly taller plants than Cyto-120 and CIM-608 cultivars on each sowing dates. Although CIM-608 cultivar produced shorter plants than CIM-620 which were statistically different from each other. During both study years, it was observed that the interactions of sowing dates with cultivars were found to be non-significant. These non-significant differences might have occurred due to the cultivar CIM-608 which produced taller plants in early sown crops $\left(15^{\text {th }}\right.$ April and $1^{\text {st }}$ May) which might have been due to the genetic difference and more tolerance to late sowing. In Table 1, results clearly depicted that with each delay in sowing of the crop showed a decrease in number of nodes plant ${ }^{-1}$ but this decrease was statistically significant to all other treatments (Table 1). Crop sown early on the $15^{\text {th }}$ April gave the maximum number of nodes plant ${ }^{-1}$, and crop sown late on the $15^{\text {th }}$ June produced significantly the minimum number of nodes plant $^{-1}(17,16)$ in both study years. Among all the cultivar treatments statistically significant differences were observed. Cultivar CIM-620 produced significantly greater number of nodes plant $^{-}$ ${ }^{1}$ than Cyto-120 and CIM-608 cultivars on each sowing dates. It is evident from the results that with each delay in sowing time the plants were shorter which results in the decrease of number of nodes plant ${ }^{-1}$

Data (Table 1) showed that inter-nodal distance of the cotton cultivars was influenced by different sowing dates and cultivars. Both the cultivars Cyto-120 and CIM-608 did not show any significant difference in inter-nodal distance. However, delay in sowing dates showed decrease in inter-nodal distance and significantly the highest distance $(3.6 \mathrm{~cm})$ was observed in crop sown early on the $15^{\text {th }}$ April, while the lowest $(3.0 \mathrm{~cm})$ inter- nodal distance was observed in crop on the $15^{\text {th }}$ June.

Results showed that Leaf area index (LAI) was significantly influenced by different treatments (Fig. 1). It was observed that late sown cotton has showed promoted effects on LAI values especially at the final harvest (100 DAS) than early sown cotton growth stages. Early sowing on the $15^{\text {th }}$ April produced significantly lesser leaf area index than sowing on the $15^{\text {th }}$ June. While among the three different cultivars CIM-608 gave higher values of LAI than Cyto-120 and CIM-620 at (100 DAS). It is evident from the results that interactions between different treatments of sowing dates and cultivars were found to be non-significant (Table 1; Fig. 2). Cultivar CIM-620 increased significantly $(\mathrm{P} \leq 0.05)$ CGR at early growth stage $(50 \mathrm{DAS})$, while later on Cyto-120 gave significantly higher CGR throughout the growing period when sown early on the $15^{\text {th }}$ April. Cultivars sown on the $1^{\text {st }}$ June 01 and on the $15^{\text {th }}$ June showed statistically similar results until 100 DAS like that of sown early but at the final harvest CIM-620 gave higher growth rate. It is also clear from the results that each delay in sowing date significantly $(\mathrm{P} \leq 0.05)$ increased growth rate during early growth stages $(50$ and 100 
DAS) while, at the final harvest each delay in sowing date significantly $(\mathrm{P} \leq 0.05)$ reduced the growth rate by all the three cultivars.

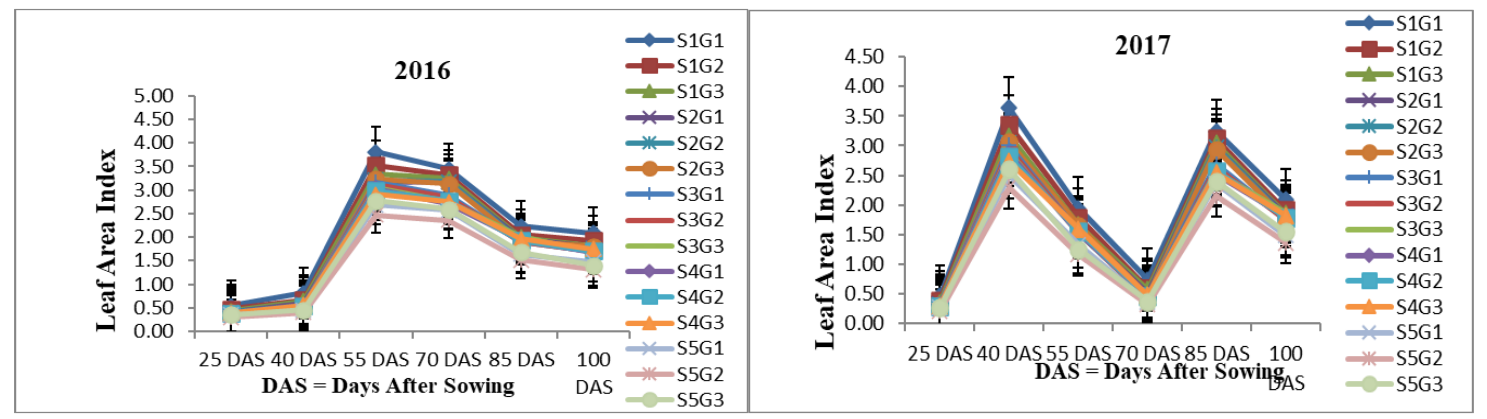

Figure 1. Relationship between LAI and yield

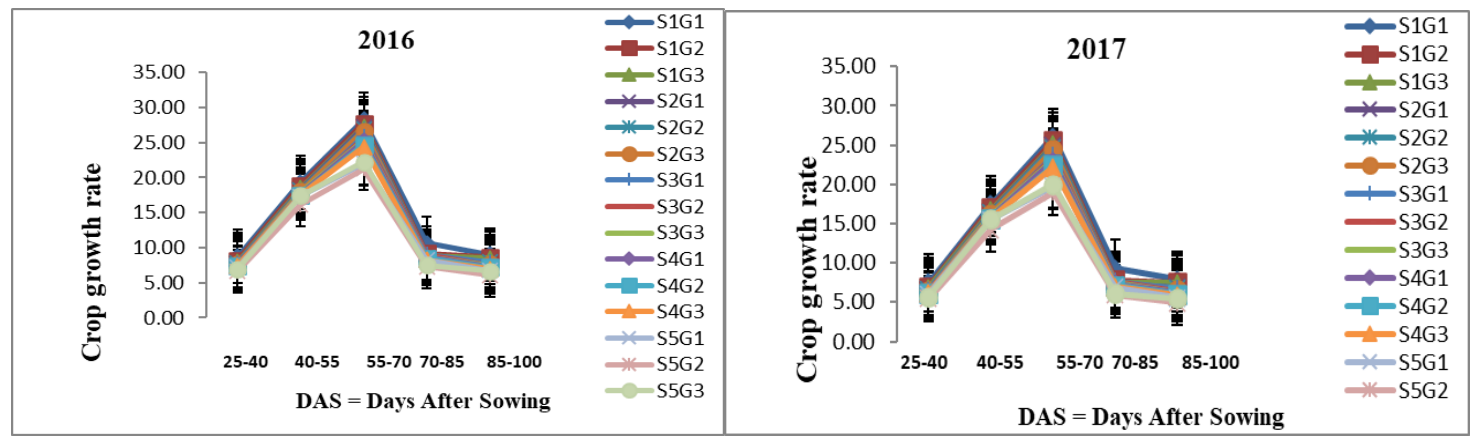

Figure 2. Relationship between CGR and yield

Table 1. Effect of different sowing time and cultivars on the yield and yield contributing factors of cotton during 2016 and 2017

\begin{tabular}{|c|c|c|c|c|c|c|c|c|c|c|c|c|}
\hline \multirow{2}{*}{$\begin{array}{c}\text { Treatments } \\
\begin{array}{c}\text { Sowing dates } \\
\text { (main plot) }\end{array}\end{array}$} & \multicolumn{2}{|c|}{ Plant height $(\mathbf{c m})$} & \multirow{2}{*}{\begin{tabular}{|c|}
$\begin{array}{c}\text { No. of nodes } \\
\text { per plant }\end{array}$ \\
2016 \\
\end{tabular}} & \multicolumn{3}{|c|}{ Nodal distance $(\mathrm{cm})$} & \multicolumn{2}{|c|}{ Leaf area index } & \multicolumn{2}{|c|}{$\begin{array}{l}\text { Crop growth } \\
\text { rate }\end{array}$} & \multicolumn{2}{|c|}{$\begin{array}{c}\text { Total fruiting } \\
\text { points }\end{array}$} \\
\hline & 2016 & 2017 & & 2017 & 2016 & 2017 & 2016 & 2017 & 2016 & 2017 & 2016 & 2017 \\
\hline $\mathrm{S}_{1}=15^{\text {th }}$ April & $131 \mathrm{a}$ & $127 \mathrm{a}$ & $32 \mathrm{a}$ & $29 a$ & $3.6 \mathrm{a}$ & $3.5 \mathrm{a}$ & $2.4 \mathrm{e}$ & $2.2 \mathrm{e}$ & $12.6 \mathrm{a}$ & $12.3 \mathrm{a}$ & $406 \mathrm{a}$ & $390 \mathrm{a}$ \\
\hline $\mathrm{S}_{2}=01^{\text {th }}$ May & $114 \mathrm{~b}$ & $115 \mathrm{~b}$ & $29 \mathrm{~b}$ & $27 \mathrm{~b}$ & $3.3 \mathrm{~b}$ & $3.2 \mathrm{~b}$ & $2.5 \mathrm{~d}$ & $2.4 \mathrm{~d}$ & $12.1 \mathrm{~b}$ & $11.8 \mathrm{~b}$ & $389 \mathrm{~b}$ & $356 \mathrm{~b}$ \\
\hline $\mathrm{S}_{3}=15^{\text {th }}$ May & $108 \mathrm{c}$ & $104 \mathrm{c}$ & $27 \mathrm{c}$ & $25 \mathrm{c}$ & $3.2 \mathrm{c}$ & $3.1 \mathrm{c}$ & $2.6 \mathrm{c}$ & $2.5 \mathrm{c}$ & $10.8 \mathrm{c}$ & $11.6 \mathrm{c}$ & $377 \mathrm{c}$ & $328 \mathrm{c}$ \\
\hline $\mathrm{S}_{4}=01^{\text {th }}$ June & $96 \mathrm{~d}$ & $91 \mathrm{~d}$ & $20 \mathrm{~d}$ & $18 \mathrm{~d}$ & $3.1 \mathrm{~d}$ & $3.0 \mathrm{~d}$ & $2.8 \mathrm{~b}$ & $2.7 \mathrm{~b}$ & $10.1 \mathrm{~d}$ & $9.6 \mathrm{~d}$ & $354 \mathrm{~d}$ & $296 \mathrm{~d}$ \\
\hline $\mathrm{S}_{5}=15^{\text {th }}$ June & $75 \mathrm{e}$ & $75 \mathrm{e}$ & $17 \mathrm{e}$ & $16 \mathrm{e}$ & $3.0 \mathrm{e}$ & $2.9 \mathrm{e}$ & $2.9 \mathrm{a}$ & $2.8 \mathrm{a}$ & $8.5 \mathrm{e}$ & $8.1 \mathrm{e}$ & $258 \mathrm{e}$ & $247 \mathrm{e}$ \\
\hline $\operatorname{LSD}(\mathrm{P} \leq 0.05)$ & 1.2 & 1.8 & 0.9 & 0.9 & 0.07 & 0.06 & 0.04 & 0.05 & 0.4 & 0.4 & 7.4 & 8.2 \\
\hline \multicolumn{13}{|l|}{$\begin{array}{c}\text { Cultivars (C) } \\
\text { (subplot) }\end{array}$} \\
\hline $\mathrm{C}_{1}=\mathrm{CIM}-620$ & $109 \mathrm{a}$ & $106 \mathrm{a}$ & $28 \mathrm{a}$ & $26 \mathrm{a}$ & $3.3 \mathrm{a}$ & $3.3 \mathrm{a}$ & $2.6 \mathrm{c}$ & $2.3 \mathrm{c}$ & $11.7 \mathrm{a}$ & $11.4 \mathrm{a}$ & 374 a & $355 \mathrm{a}$ \\
\hline $\mathrm{C}_{2}=$ Cyto -120 & $105 \mathrm{~b}$ & $102 \mathrm{~b}$ & $25 \mathrm{~b}$ & $23 \mathrm{~b}$ & $3.2 \mathrm{~b}$ & $3.2 \mathrm{~b}$ & $2.7 \mathrm{~b}$ & $2.4 \mathrm{~b}$ & $10.6 \mathrm{~b}$ & $10.4 \mathrm{~b}$ & $357 \mathrm{~b}$ & $319 b$ \\
\hline $\mathrm{C}_{3}=\mathrm{CIM}-608$ & $101 \mathrm{c}$ & $98 \mathrm{c}$ & $23 \mathrm{c}$ & $21 \mathrm{c}$ & $3.2 \mathrm{~b}$ & $3.1 \mathrm{~b}$ & $2.8 \mathrm{a}$ & $2.6 \mathrm{a}$ & $10.1 \mathrm{~b}$ & $9.7 \mathrm{c}$ & $340 \mathrm{c}$ & $298 \mathrm{c}$ \\
\hline $\operatorname{LSD}(\mathrm{P} \leq 0.05)$ & 1.9 & 1.3 & 0.9 & 0.8 & 0.07 & 0.06 & 0.04 & 0.04 & 0.2 & 0.2 & 6.9 & 7.5 \\
\hline$(\mathbf{S} * \mathbf{C})$ & NS & NS & NS & NS & NS & NS & NS & NS & NS & NS & NS & NS \\
\hline
\end{tabular}

Mean values having similar letters were not different from each other $\mathrm{p} \leq 0.05$; NS $=$ Non-significant

The interactive effect between different sowing dates and cultivars were found to be non-significant during both study years (Table 1). The results indicated that different 
sowing dates also significantly influenced the fruiting points of the cultivars as each delay in sowing significantly $(\mathrm{P} \leq 0.05)$ reduced the number of fruiting points. The highest number 406 and $390\left(\mathrm{~m}^{-2}\right)$ were observed in crops sown on the $15^{\text {th }}$ April, while the lowest fruiting parts were produced in late sown crop on the $15^{\text {th }}$ June during both the study years (Table 1).

Among the cultivars, CIM-620 significantly $(\mathrm{P} \leq 0.05)$ produced more number of fruiting points than other cultivars. The highest fruiting point $364 \mathrm{~m}^{-2}$ was produced in CIM-620 while the lowest $\left(319 \mathrm{~m}^{-2}\right)$ was observed in cultivar CIM-608 However, the interaction between sowing dates and cultivars were found to be non-significant.

The results of Table 2 showed that there were significant differences among different treatments i.e. sowing dates and cultivars and interactions between sowing dates and cultivars were found to be significant for boll weight and seed cotton yield (Table 2). The maximum $\left(138 \mathrm{~m}^{-2}\right)$ number of bolls were obtained by the combination of CIM-620 with early sowing of crop while the lowest $\left(46 \mathrm{~m}^{-2}\right)$ number of bolls were observed with CIM-608 sown on the $15^{\text {th }}$ June. This significant effect might have occurred after maintaining the optimum plant population through thinning and gap filling at early stages of the crop in early sowing. Results relating to boll weight revealed that there were significant differences among different treatments of sowing dates and cultivars (Table 2). The crop sown on the $15^{\text {th }}$ June produced the highest average boll weight of $(2.9 \mathrm{~g})$ while the lowest average boll weight of $(2.3 \mathrm{~g})$ was observed with sowing of cotton on the $15^{\text {th }}$ April. Accordingly, crop sown on the $15^{\text {th }}$ April gave lower boll weight than those sown on the $1^{\text {st }}$ May that produced significantly higher average boll weight of $(2.5 \mathrm{~g})$ during both years of experimentation. Similarly, crop sown on the $1^{\text {st }}$ June, also gave significantly higher boll weight than crop sown on the $15^{\text {th }}$ May. In case of various cultivars, the cultivar CIM-608 gave significantly $(\mathrm{P} \leq 0.05)$ higher boll weight than CIM-620.

Table 2. Effect of different sowing time and cultivars on the yield and quality parameters of cotton during 2016 and 2017

\begin{tabular}{|c|c|c|c|c|c|c|c|c|c|c|}
\hline \multirow{2}{*}{$\begin{array}{c}\text { Treatments } \\
\begin{array}{c}\text { Sowing dates } \\
\text { (main plot) }\end{array}\end{array}$} & \multicolumn{2}{|c|}{$\begin{array}{l}\text { No of bolls } \\
\text { plant }^{-1}\end{array}$} & \multicolumn{2}{|c|}{ Boll weight (g) } & \multicolumn{2}{|c|}{$\begin{array}{c}\text { Seed cotton yield } \\
\left(\mathrm{kg} \mathrm{ha}^{-1}\right)\end{array}$} & \multicolumn{2}{|c|}{ Staple length $(\mathrm{mm})$} & \multicolumn{2}{|c|}{ Fiber strength } \\
\hline & 2016 & 2017 & 2016 & 2017 & 2016 & 2017 & 2016 & 2017 & 2016 & 2017 \\
\hline $\mathrm{S}_{1}=15^{\text {th }}$ April & $128 \mathrm{a}$ & 119 a & $2.4 \mathrm{e}$ & $2.2 \mathrm{e}$ & 2759 a & 2569 a & $28.4 \mathrm{a}$ & $27.9 \mathrm{a}$ & $94.8 \mathrm{a}$ & $94.3 \mathrm{a}$ \\
\hline $\mathrm{S}_{2}=01^{\text {th }}$ May & $116 \mathrm{~b}$ & $105 \mathrm{~b}$ & $2.5 \mathrm{~d}$ & $2.4 \mathrm{~d}$ & $2528 \mathrm{~b}$ & $2281 \mathrm{~b}$ & $27.4 \mathrm{~b}$ & $26.6 \mathrm{~b}$ & $93.1 \mathrm{~b}$ & $93.1 \mathrm{~b}$ \\
\hline $\mathrm{S}_{3}=15^{\text {th }}$ May & $96 c$ & $83 \mathrm{c}$ & $2.6 \mathrm{c}$ & $2.5 \mathrm{c}$ & $2352 \mathrm{c}$ & $2050 \mathrm{c}$ & $26.8 \mathrm{c}$ & $26.1 \mathrm{c}$ & $92.5 \mathrm{c}$ & $91.9 \mathrm{c}$ \\
\hline $\mathrm{S}_{4}=01^{\text {th }}$ June & $82 \mathrm{~d}$ & $71 \mathrm{~d}$ & $2.8 \mathrm{~b}$ & $2.7 \mathrm{~b}$ & $1891 \mathrm{~d}$ & $1783 \mathrm{~d}$ & $26.3 \mathrm{~d}$ & $25.4 \mathrm{~d}$ & $91.9 \mathrm{~d}$ & $91.3 \mathrm{~d}$ \\
\hline $\mathrm{S}_{5}=15^{\text {th }}$ June & $65 \mathrm{e}$ & $51 \mathrm{e}$ & $2.9 \mathrm{a}$ & $2.8 \mathrm{a}$ & $1387 \mathrm{e}$ & $1264 \mathrm{e}$ & $25.7 \mathrm{e}$ & $25.0 \mathrm{e}$ & $90.7 \mathrm{e}$ & $90.0 \mathrm{e}$ \\
\hline $\operatorname{LSD}(\mathrm{P} \leq 0.05)$ & 4.8 & 2.5 & 0.04 & 0.05 & 39.7 & 36.0 & 0.3 & 0.2 & 0.2 & 0.4 \\
\hline \multicolumn{11}{|l|}{$\begin{array}{l}\text { Cultivars } \\
\text { (sub plot) }\end{array}$} \\
\hline $\mathrm{C}_{1}=\mathrm{CIM}-620$ & $111 \mathrm{a}$ & 99 a & $2.6 \mathrm{c}$ & $2.3 \mathrm{c}$ & 2456 a & $2257 \mathrm{a}$ & $27.6 \mathrm{a}$ & $26.8 \mathrm{a}$ & $93.4 \mathrm{a}$ & $92.7 \mathrm{a}$ \\
\hline $\mathrm{C}_{2}=$ Cyto -120 & $95 \mathrm{~b}$ & $84 \mathrm{~b}$ & $2.7 \mathrm{~b}$ & $2.4 \mathrm{~b}$ & $2124 b$ & $1939 \mathrm{~b}$ & $26.9 \mathrm{~b}$ & $26.2 \mathrm{~b}$ & $92.5 \mathrm{~b}$ & $92.2 \mathrm{~b}$ \\
\hline $\mathrm{C}_{3}=\mathrm{CIM}-608$ & $87 \mathrm{c}$ & $75 \mathrm{c}$ & $2.8 \mathrm{a}$ & $2.6 \mathrm{a}$ & $1971 \mathrm{c}$ & $1773 \mathrm{c}$ & $26.5 \mathrm{c}$ & $25.7 \mathrm{c}$ & $91.9 \mathrm{c}$ & $91.5 \mathrm{c}$ \\
\hline $\operatorname{LSD}(\mathrm{P} \leq 0.05)$ & 3.6 & 2.6 & 0.04 & 0.04 & 46.4 & 38.8 & 0.2 & 2.6 & 0.2 & 0.2 \\
\hline Interaction & NS & NS & $*$ & $*$ & $*$ & $*$ & NS & NS & NS & NS \\
\hline
\end{tabular}

Mean values having similar letters were not different from each other $\mathrm{p} \leq 0.05$; NS $=$ Non-significant

It is evident from the results that interactions between sowing dates and cultivar treatments were found to be non-significant. Sowing dates and cultivars had significant 
effect on seed cotton yield (Table 2). As each delay in sowing date reduced significantly the seed cotton yield and the highest yield of $2759 \mathrm{~kg} \mathrm{ha}^{-1}$ and $2569 \mathrm{~kg} \mathrm{ha}^{-1}$ was produced when crop was sown early on the $15^{\text {th }}$ April and the lowest yield of $1387 \mathrm{~kg}$ $\mathrm{ha}^{-1}$ and $1264 \mathrm{~kg} \mathrm{ha}^{-1}$ was produced with late sown crop on the $15^{\text {th }}$ June during both years of the experimentation 2016 and 2017, respectively. Cultivar CIM-620 produced significantly more seed cotton yield $\left(2456 \mathrm{~kg} \mathrm{ha}^{-1}\right.$ and $\left.2257 \mathrm{~kg} \mathrm{ha}^{-1}\right)$ than CIM-608 that gave lower yield of $1971 \mathrm{~kg} \mathrm{ha}^{-1}$ and $1773 \mathrm{~kg} \mathrm{ha}^{-1}$ during 2016 and 2017, respectively. It is clear from the results that each delay in sowing time significantly reduced seed cotton yield of all the cultivars (Table 2).

Sowing dates and cultivars had significant effect on staple length (Table 2). All the cultivars produced the highest staple length with early sowing treatment on the $15^{\text {th }}$ April while the lowest staple length was recorded with late sown crop on the $15^{\text {th }}$ June. The results in Table 2 revealed that different sowing dates influenced significantly the fiber strength of the cultivars. Similarly, each delay in sowing produced significantly week fiber strength. The highest fiber strength of 94.8 and 94.3 (tppsi) was observed in early sown crop on the $15^{\text {th }}$ April, while the lowest fiber strength of 90.7 and 90.0 (tppsi) was produced in late sown crop on the $15^{\text {th }}$ June 15 during both study years 2016 and 2017, respectively (Table 2).

Among the cultivars, CIM-620 produced significantly higher fiber strength 93.1 (tppsi) while the lowest fiber strength (91.7 tppsi) was observed in CIM-608 cultivar. Moreover, the interaction between sowing dates and cultivars was found to be nonsignificant.

\section{Economic analysis}

Data regarding economic analysis is in Table 3 showed that net income and benefit cost ratio were decreased linearly as the delay in sowing time during both years 2016 and 2017. The maximum net income of Rs. 155725 in 2016 and Rs. 142365 in 2017 was achieved with combination of (Sowing of cotton at $15^{\text {th }}$ April $\times$ CIM-620), while the minimum net income of Rs. 8285 in 2016 and Rs. 2125 in 2017 was achieved with combination of (sowing of the crop at $15^{\text {th }}$ of May $\times$ CIM-608), respectively. The maximum benefit cost ratio (2.90 and 2.74) was achieved in treatment combination of (Sowing of cotton at $15^{\text {th }}$ April $\times$ CIM-620), in 2016 and 2017, respectively. While the minimum benefit cost ratio (1.10 and 0.97) was achieved in treatment combination of (sowing of the crop at $15^{\text {th }}$ of May $\times$ CIM-608) in 2016 and 2017, respectively.

\section{Discussion}

Different planting dates significantly affected the growth, Leaf area index (LAI), leaf area duration (LAD), No. of sympodial branches plant ${ }^{-1}$, total bolls plant ${ }^{-1}$, average boll weight, total dry matter and seed cotton yield of cotton (Table 1). Likewise, cultivars also differed significantly for the growth, LAI, LAD and yield and yield contributing traits. The early sown cotton crop gets benefit of nutrients and more interrupted radiation due to increase in the growth period (Ali et al., 2009). Cultivars vary in their genetic makeup and respond differently to various biotic and abiotic stresses in addition to climatic conditions. So, cultivar selection and proper sowing time are key factors to enhance seed cotton yield under different agro-ecological zones (Bange and Milroy, 2014; Iqbal et al., 2012). Cotton growth and development is greatly impacted by sowing date, especially during flower initiation and development, resulting in delayed crop 
maturity (Wei et al., 2017). Late planting often delays flower initiation and extends the boll setting period relative to normal planted crop (Wei et al., 2017; Muharam et al., 2014; Zhao et al., 2012)., Delay in Sowing dates prolonged crop growth period due to low temperature (Bachubhai et al., 2016). The increase might be due to a longer cropping season which allows the crop to utilize available resources (e.g. light) and produce more fruit for an extended time period. The reduction in yield and yield contributors were mainly attributed to a shorter growing season and that poor light interception reduces leaf photosynthetic capacity and nutrient uptake (Khan et al., 2017). Late planted crop caused substantial reduction in yield due to low temperature and poor light interception at the end of the season (Liu et al., 2015; Cao et al., 2016). The late planting of cotton decreases the boll size and weight (Ali et al., 2009). The more seed cotton yield in planting date $\left(15^{\text {th }}\right.$ May) might be due to longer growing period availability and good crop establishment under mild temperature of early season. The late sowing of cotton decreases the yield contributing traits and ultimately the seed cotton yield (Arshad et al., 2007; Ali et al., 2009; Iqbal et al., 2004; Farid et al., 2017).

Table 3. Economic analysis as affected by different sowing time on the different cultivars of cotton during 2016 and 2017

\begin{tabular}{|c|c|c|c|c|c|c|c|c|c|c|c|c|}
\hline \multirow[t]{2}{*}{$\begin{array}{c}\text { Treatme } \\
\text { nts }\end{array}$} & \multicolumn{2}{|c|}{$\begin{array}{l}\text { Seed cotton yield } \\
\left(\mathrm{kg} \mathrm{ha}^{-1}\right)\end{array}$} & \multicolumn{2}{|c|}{$\begin{array}{c}\text { Value } \\
\left(\text { Rs. ha' }{ }^{-1}\right)\end{array}$} & \multicolumn{2}{|c|}{$\begin{array}{l}\text { Gross income } \\
\quad(\text { Rs. ha-1) }\end{array}$} & \multicolumn{2}{|c|}{$\begin{array}{l}\text { Total cost } \\
\left.\text { (Rs. ha' }{ }^{-1}\right)\end{array}$} & \multicolumn{2}{|c|}{$\begin{array}{l}\text { Net return } \\
\left(\text { Rs. ha' } \mathbf{a}^{-1}\right)\end{array}$} & \multicolumn{2}{|c|}{$\begin{array}{c}\text { Benefit cost } \\
\text { ratio } \\
\left(\text { Rs. ha }^{-1}\right)\end{array}$} \\
\hline & 2016 & 2017 & 2016 & 2017 & 2016 & 2017 & 2016 & 2017 & 2016 & 2017 & 2016 & 2017 \\
\hline $\mathrm{S}_{1} \mathrm{C}_{1}$ & 2970 & 2803 & 237600 & 224240 & 237600 & 224240 & 81875 & 81875 & 155725 & 142365 & 2.90 & 2.74 \\
\hline $\mathrm{S}_{1} \mathrm{C}_{2}$ & 2854 & 2684 & 228320 & 214720 & 228320 & 214720 & 81875 & 81875 & 146445 & 132845 & 2.79 & 2.62 \\
\hline $\mathrm{S}_{1} \mathrm{C}_{3}$ & 2788 & 2640 & 223040 & 211200 & 223040 & 211200 & 81875 & 81875 & 141165 & 129325 & 2.72 & 2.58 \\
\hline $\mathrm{S}_{2} \mathrm{C}_{1}$ & 2640 & 2520 & 211200 & 201600 & 211200 & 201600 & 81875 & 81875 & 129325 & 119725 & 2.58 & 2.46 \\
\hline $\mathrm{S}_{2} \mathrm{C}_{2}$ & 2522 & 2412 & 201760 & 192960 & 201760 & 192960 & 81875 & 81875 & 119885 & 111085 & 2.46 & 2.36 \\
\hline $\mathrm{S}_{2} \mathrm{C}_{3}$ & 2476 & 2270 & 198080 & 181600 & 198080 & 181600 & 81875 & 81875 & 116205 & 99725 & 2.42 & 2.22 \\
\hline $\mathrm{S}_{3} \mathrm{C}_{1}$ & 2328 & 2102 & 186240 & 168160 & 186240 & 168160 & 81875 & 81875 & 104365 & 86285 & 2.27 & 2.05 \\
\hline $\mathrm{S}_{3} \mathrm{C}_{2}$ & 2264 & 2046 & 181120 & 163680 & 181120 & 163680 & 81875 & 81875 & 99245 & 81805 & 2.21 & 2.00 \\
\hline $\mathrm{S}_{3} \mathrm{C}_{3}$ & 2141 & 1872 & 171280 & 149760 & 171280 & 149760 & 81875 & 81875 & 89405 & 67885 & 2.09 & 1.83 \\
\hline $\mathrm{S}_{4} \mathrm{C}_{1}$ & 1857 & 1637 & 148560 & 130960 & 148560 & 130960 & 81875 & 81875 & 66685 & 49085 & 1.81 & 1.60 \\
\hline $\mathrm{S}_{4} \mathrm{C}_{2}$ & 1740 & 1462 & 139200 & 116960 & 139200 & 116960 & 81875 & 81875 & 57325 & 35085 & 1.70 & 1.43 \\
\hline $\mathrm{S}_{4} \mathrm{C}_{3}$ & 1682 & 1350 & 134560 & 108000 & 134560 & 108000 & 81875 & 81875 & 52685 & 26125 & 1.64 & 1.32 \\
\hline $\mathrm{S}_{5} \mathrm{C}_{1}$ & 1432 & 1287 & 114560 & 102960 & 114560 & 102960 & 81875 & 81875 & 32685 & 21085 & 1.40 & 1.26 \\
\hline $\mathrm{S}_{5} \mathrm{C}_{2}$ & 1320 & 1157 & 105600 & 92560 & 105600 & 92560 & 81875 & 81875 & 23725 & 10685 & 1.29 & 1.13 \\
\hline $\mathrm{S}_{5} \mathrm{C}_{3}$ & 1127 & 997 & 90160 & 79760 & 90160 & 79760 & 81875 & 81875 & 8285 & 2115 & 1.10 & 0.97 \\
\hline
\end{tabular}

\section{Conclusion}

It is concluded from the present study that cultivar CIM-620 has a potential of bearing maximum No. of bolls and lower shedding percentage causes increased performance and output and lint percentage with more fiber brightness. The crop sown earlier on $15^{\text {th }}$ May produced the higher number of fruiting points, highest fruit and boll numbers which causes maximum yield. Similarly, high nitrogen fertilized plots exhibited earliness, higher number of fruiting points, more boll numbers and higher seed cotton yield.

In the future, cotton crop should be cultivated on different locations to check its behavior under time and climatic conditions. It should be cultivated under different time interval in Wheat-cotton belt to minimize the time conflict between these two crops and 
their effect on the crop yield. Cultivars used in the trials should be evaluated under the green house and lab conditions for better recommendation to the cotton growers. To safeguard the environment, sustainable production of cotton with minimum utilization of resources as the aim of modern agriculture should be operated in Pakistan.

\section{REFERENCES}

[1] Ahmed, A. U. H., Ali, R., Zamir, S. I., Mehmood, N. (2009): Growth, yield and quality performance of cotton cultivar BH-160 (Gossypium hirsutum L.). - J. Anim. Plant Sci. 19: 189-192.

[2] Ali, H., Hameed, R. A. (2011): Growth, yield and yield components of American cotton (Gossypium hirsutum L.) as affected by cultivars and nitrogen fertilizer. - Int. J. Sci. \& Engine. Res. 2(7): 1-13.

[3] Ali, H., Afzal, M. N., Ahmad S., Muhammad D. (2009a): Effect of cultivars and sowing dates on yield and quality of cotton (Gossypium hirsutum L.) crop. - J. Food Agri. Environ. 7: 244-247.

[4] Ali, H., Afzal, M. N., Muhammad, D. (2009b): Effect of sowing dates and plant spacing on growth and dry matter portioning in cotton (Gossypium hirsutum L.). - Pak. J. Bot. 41(5): 2145-2155.

[5] Arshad, M., Wajid, A., Maqsood, M., Hussain, K., Aslam, M., Ibrahim, M. (2007): Response of growth, yield \& quality of different cotton cultivars to sowing dates. - Pak. J. Agri. Sci. 44: 208-212.

[6] Bachubhai, A., Monpara, D., Vaghasia, R. (2018): Optimizing sowing time and row spacing for summer sesame growing in semi-arid environments of India. - Int. J. Curr. Res. Acad Rev. 4: 122-131.

[7] Bozbek T., Sezener, V., Unay, A. (2006): The effect of sowing date and plant density on cotton yield. - J. Agron. 5: 122-125.

[8] Cao, T. V., Oumarou, P., Gawrysiak, G., Klassou, C., Hau, B. (2016): Short-season cotton (Gossypium hirsutum L.) may be a suitable response to late planting in subSaharan regions. - Field Crops Res. 1: 9-20.

[9] Farid, M. A., Ijaz, M., Hussain, S., Hussain, M., Farooq, O., Sattar, A., Sher, A., Wajid, A., Ullah, A., Faiz, M. R. (2017): Growth and yield response of cotton cultivars at different planting dates. - Pak. J. Life Soc. Sci. 15(3): 158-162.

[10] Govt. of Pakistan (2017): Economic Survey of Pakistan. - Federal Bureau of Statistics, Islamabad, Pakistan.

[11] Hunt, R. (1978): Plant Growth Analysis. - Edward Arnold, London, pp. 26-38.

[12] Iqbal Bange, M. P., Milroy, S. P. (2004): Growth and dry matter partitioning of diverse cotton genotypes. - Field Crops Research 87: 73-87.

[13] Iqbal, J., Wajid, S. A., Ahmad, A., Arshad, M. (2012): Comparative studies on seed cotton yield in relation to nitrogen rates and sowing dates under diverse agro-environment of Punjab. - Pakistan Journal of Science 64: 59-63.

[14] Khan, A., Najeeb, U., Wang, L., Tan, D. K. Y., Yang, G., Munsif, F., Hafeez, A. (2017): Planting density and sowing date strongly influence growth and lint yield of cotton crops. - Field Crops Res. 209: 129-135.

[15] Killi, F., L., Mustafayev, S. (2005): Genetic and environmental variability in yield, yield components and lint quality traits of cotton. - Int. J. Agric. Biol. 7: 1007-1010.

[16] Liu, J., Meng, Y., Chen, J., Lv, F., Ma, Y., Chen, B., Oosterhuis, D. M. (2015): Effect of late planting and shedding on cotton yield and fiber quality formation. - Field Crops Res. 183: $1-13$. 
[17] Muharam, F. M., Bronson, K. F., Maas, S. J., Ritchie, G. L. (2014): Inter-relationships of cotton plant height canopy width, ground cover and plant nitrogen status indicators. Field Crops Res. 169: 58-69.

[18] Subhan, M., Khan, H. U., Ahmed, R. O. (2001): Population Analysis of Some Agronomic and Technological Characteristics of Upland Cotton (Gossypium hirsutumL.). - Journal of Biological Sciences 1: 120-123.

[19] Watson, D. J. (1952): The physiological basis of variation in yield. - Adv. Agron. 4: 101145.

[20] Wei, H. U., Chen, M. L., Zhao, W. Q., Chen, B. L., Wang, Y. H., Wang, S. S., Zhao, Z. G. (2017): The effects of sowing date on cottonseed properties at different fruiting-branch positions. - J. Integr. Agric. 16: 1322-1330.

[21] Zhao, W., Wang, Y., Shu, H., Li, J., Zhou, Z. (2012): Sowing date and boll position affected boll weight: fiber quality and fiber physiological parameters in two cotton (Gossypium hirsutum L.) cultivars. - African. J. Agric. Res. 7: 6073-6608.

\section{APPENDIX}

\section{Economic analysis}

Fixed cost

\begin{tabular}{|c|c|c|c|}
\hline Input charges & Number of operations & Price per unit (Rs) & Total amount (Rs) \\
\hline \multicolumn{4}{|l|}{ 1) Preparation of seed bed } \\
\hline Cultivations & 4 & 1250/ha & 5000 \\
\hline Planking & 2 & 1250/ha & 2500 \\
\hline Preparation of ridge & 1 & $3000 / \mathrm{ha}$ & 3000 \\
\hline \multicolumn{4}{|l|}{ 2) Seeding expenditures } \\
\hline Cotton seed & $25 \mathrm{~kg} / \mathrm{ha}$ & Rs. 300/kg & 8125 \\
\hline Manual sowing & 10 man days & 250/man/day & 2500 \\
\hline \multicolumn{4}{|l|}{ 3) Weeds removal } \\
\hline Interculture & 1 & 3000/ha & 3000 \\
\hline \multicolumn{4}{|l|}{ 4) Plant protective measures } \\
\hline Carbofuran & 2.5 Packs & 750/pack & 1875 \\
\hline Charges of application & $1 \mathrm{man} /$ day & 250/man/day & 250 \\
\hline \multicolumn{4}{|l|}{ 5) Irrigation } \\
\hline Water rates (Abyana) & 1 ha & $375 / \mathrm{ha}$ & 375 \\
\hline Water course cleaning & 5 man days & 250/man/day & 1250 \\
\hline Charges of application & 5 man days & 250/man/day & 1250 \\
\hline 6) Cost of fertilizer & $\begin{array}{c}\text { 10-12 bags }+ \text { application } \\
\text { charges } 2 \text { man/day }\end{array}$ & 18500/ha & 18500 \\
\hline 7) Cost of picking & $10 \mathrm{man} / \mathrm{day}$ & 300/man/day & 3000 \\
\hline 8) Rent of land & 6 months & 62500/ha/anum & 31250 \\
\hline Expenses from 1-8 & - & - & 81875 \\
\hline Total Cost & & & 81875 \\
\hline
\end{tabular}

